\title{
Determining the harvest time of camu-camu [Myrciaria dubia (H.B.K.) McVaugh] using measured pre-harvest attributes
}

\author{
Leandro Camargo Neves ${ }^{\mathrm{a}, *}$, Vanuza Xavier da Silva ${ }^{\mathrm{b}, 1}$, Edvan Alves Chagas $^{\mathrm{c}}$, \\ Christinny Giselly Barcelar Lima ${ }^{\mathrm{d}}$, Sergio Ruffo Roberto ${ }^{\mathrm{e}}$ \\ a Federal University of Roraima (UFRR), Cauamé Campus, BR-174 Km 12, Monte Cristo, Boa Vista-RR, CEP: 69301-970, Brazil \\ ${ }^{\mathrm{b}}$ Agronomy Graduate Program of the Federal University of Roraima (UFRR), Cauamé Campus, BR-174 Km 12, Monte Cristo, Boa Vista-RR, \\ CEP: 69301-970, Brazil \\ ${ }^{\mathrm{c}}$ Embrapa Roraima, BR 174, km 08, C.P. 133, Industrial district, CEP: 69301-970, Boa Vista-RR, Brazil \\ d Embrapa Roraima, BR 174, km 08, C.P. 133, Industrial district, CEP: 69301-970, Boa Vista-RR, Brazil \\ e Universidade Estadual de Londrina, UEL-CCA, Agronomy Departament, Campus Universitário, Jd. Perobal, PR - Brasil - Mailbox: 6001.,CEP: 86051990, \\ Londrina, Brazil
}

\section{A R T I C L E I N F O}

\section{Article history:}

Received 30 October 2014

Received in revised form 28 January 2015

Accepted 5 February 2015

\section{Keywords:}

Maturity stages

Qualitative attributes

Ascorbic acid

Amazon fruit

\begin{abstract}
A B S T R A C T
The characterization of the physical, chemical, and physiological parameters of camu-camu fruit at various stages of development may help to determine the optimal harvest time of this fruit. Camu-camu fruits from a rural property in the municipality of Cantá/RR were marked and harvested at 53,60, 67, 74, 81, 88, 95, and 102 days after anthesis (DAA) during six seasons (years) of study. The following attributes were measured: fresh weight, diameter, total soluble solids (TSS), starch, titratable acidity (TA), the TSS/TA ratio, total and reducing sugars, total and soluble pectins, pectic enzymes, vitamin $C$ content, and the production of $\mathrm{CO}_{2}$ and ethylene. The combination of the absence of a climacteric peak in the respiratory pattern and the low and invariable production of ethylene during development indicates that camu-camu fruit is non-climacteric. The best harvest time for this fruit occurred between 88 and 95 days. During this period, measured parameters such as coloration ( $85 \%$ and $100 \%$ red, respectively), high TSS:TA ratio, reduced TA, and high TSS, reducing sugar, soluble pectin, and vitamin $C$ concentrations achieved their optimal.
\end{abstract}

(c) 2015 Elsevier B.V. All rights reserved.

\section{Introduction}

Camu-camu is an Amazonian fruit that deserves attention, in general, for its content of vitamin C. Commercially, the recent introduction of this fruit into the world market, especially in America and in centers of high consumption of fruits such as Europe and Asia, has aroused great interest by local farmers. In this sense, camu-camu has awakened interests of industrial sectors such as the pharmaceutical, cosmetics, and food industries due the natural bio compounds that may be the extracted from its skin and pulp and, possibly, with high antioxidant activities (Smiderle and Sousa, 2008).

\footnotetext{
* Corresponding author. Tel.: +55 95362729 03; fax: +55 9536272903.

E-mail addresses: rapelbtu@hotmail.com (L.C. Neves),vanuzaxs@hotmail.com (V.X.d. Silva), echagas@cpafrr.embrapa.br (E.A.Chagas), sroberto@uel.br (S.R. Roberto).

1 Tel.: +55 95362729 03; fax: +55 9536272903 .
}

As mentioned, camu-camu fruits have the highest vitamin $\mathrm{C}$ content of all fruits studied to date (Alves et al., 2002; Rodrigues et al., 2001; Yuyama et al., 2002). Yuyama et al. (2002) measured very high concentrations of vitamin $\mathrm{C}$ in fruits from a natural habitat in the eastern portion of Roraima, Brazil, ranging from $3571 \mathrm{mg}$ of ascorbic acid/100 $\mathrm{g}$ fresh pulp in the Rio Mau region to $6112 \mathrm{mg}$ of ascorbic acid/100 $\mathrm{g}$ fresh pulp in the Rio Tacutu region. These surpass those measured in the acerola ( $1790 \mathrm{mg} / 100 \mathrm{~g}$ pulp), a fruit that was previously considered to have the highest of vitamin $C$. Because the camu-camu is very high in vitamin $C$, a vitamin that is not synthesized by the human body and must therefore be consumed in the diet, there is a strong demand for this fruit in the natural products market.

The vitamin $C$ content, similar to other phytochemical profiles of the camu-camu, is known to change throughout the fruit's stages of maturation. The occurrence of the ripening stage, in particular, significantly affects the physical characteristics and chemical composition of the camu-camu (Andrade et al., 1995). Camu-camu fruits are green when unripe and turn red or purple during 
maturation and ripening because of the presence of anthocyanins (Zanatta et al., 2005). According to Yuyama et al. (2011), red camu-camu fruits have greater vitamin $\mathrm{C}$, but other studies have reported higher concentrations in unripe fruits (Alves et al., 2002). This discrepancy is the main obstacle to establishing the commercial production of camu-camu in Brazil because numerous small producers use skin color as the only indicator for determining the optimal time of harvest. Notably, the timing of the harvest can be critical for maintaining high concentrations of vitamin $C$ and other biomolecules.

The ideal ripening stage for harvesting camu-camu can be determined by evaluating maturation and ripening curves that consider chemical and physical changes, such as weight loss and changes in the total soluble solids, titratable acidity, and vitamin C (Giovannoni, 2004). To produce these curves, physical, chemical, and physiological parameters of the fruit are measured throughout their development (Andrade et al., 1995).

The aim of the present study was to characterize the physical, chemical, physico-chemical, and physiological parameters of camu-camu fruits during various stages of development to determine the ideal harvest time of camu-camu in the state of Roraima.

\section{Materials and methods}

The fruits used in this experiment were harvested during six seasons (years) of study from a rural property located in the county/state of Cantá/Roraima (RR), near one of the Branco river, $60 \mathrm{~km}$ from Boa Vista (the state capital).

To obtain fruits from the entire camu-camu population, approximately 2000 inflorescences from 40 plants (representing $90 \%$ of the plants in the area) were marked. However, because a single inflorescence can contain materials at various stages, buds at later stages (developing ovaries) and earlier stages (young buds that were only a few days old) were removed when necessary, thereby leaving only the buds at the previously described stage of interest. These floral buds were marked with colored wire and a label containing the date and an ID number was attached. The floral buds were monitored weekly from the date of marking until the start of fruit harvesting.

Fruits were harvested every seven days, starting from the anthesis of the inflorescences (Fig. 1). Fruits were harvested at eight time points $(53,60,67,74,81,88,95$, and 102 days after anthesis-DAA).

Approximately 120 fruits, representative of the entire population, were collected at each harvest. On the day of the harvest, the fruits were placed in plastic pots inside Styrofoam boxes containing ice and then transported to the Laboratory of Food Technology-UFRR and; care was taken to avoid direct contact between the fruit and the ice. In the laboratory, the fruits were cleaned using pure water and dried at room temperature $\left(25 \pm 2{ }^{\circ} \mathrm{C}\right.$ and $75 \pm 2 \%$ R.H.), allowing the excess water to evaporate naturally $( \pm 2 \mathrm{~h}$ ). After the fruits were cleaned, 30 samples (weighing $276.3 \pm 106.0 \mathrm{~g}$ ) were randomly selected for physical analysis and divided in two groups:(a) Destructive analysis: three replicates of 10 fruits weighing $92.0 \pm 36.0 \mathrm{~g}$; and, (b) Non-destructive analysis: likewise, approximately 90 fruits (weighing $828.8 \pm 319.0 \mathrm{~g}$ were divided into three replicates of 30 fruits for the measurement of $\mathrm{CO}_{2}$ and ethylene production, and these fruits were kept intact until the end of the experiment.

Peels and pulps, without seeds, from each replicate, were mixed and crushed to obtain a commingled mass of the whole fruit. Only for the vitamin $C$ analysis that peel and pulp were set apart and measured separately.

All the evaluations were performed weekly and, measured no more than $50 \pm 5$ min after each specifically harvest time. Physical measurements, total soluble solids content, and titratable acidity, as well as the collect and analysis of gases $\left(\mathrm{CO}_{2}\right.$ and ethylene), were performed immediately after each harvest. For the other analysis, were prepared samples (25-50 g of each replicate) that were frozen at $-40^{\circ} \mathrm{C}$. The frozen samples were used to measure the starch, total and reducing sugars, total soluble pectins, and pectic enzymes for each period. About $20 \mathrm{~g}$ of each replicate were lyophilized at $200 \mu \mathrm{m} \mathrm{Hg}$ and $-40^{\circ} \mathrm{C}$ and stored in a freezer for purposes of preservation. Analyses of vitamin $C$ concentrations were performed in the Plant Bioactive and Bioprocessing Research Laboratory TAMU/USA.

The following analyses were performed in all treatments (fresh fruits):

\subsection{Fresh pulp (g)}

The mass of fresh pulp was measured by weighing 10 fruits (randomly chosen) from each replicate and dividing the total weight by the number of fruits (10), thereby obtaining the mean of individual fresh weight.

\subsection{Polar and equatorial diameter $(\mathrm{mm})$}

A digital caliper was used to measure the polar and equatorial diameters of 10 fruits per replicate. The equatorial diameter was measured horizontally, and the polar diameter was measured vertically from pole to pole using the location of the stem cavity as a reference point.

\section{3. $\mathrm{CO}_{2}$ and ethylene production}

$\mathrm{CO}_{2}$ and ethylene production analyses were performed according to the methods described by Prill et al. (2012). Briefly, 10 fruits weighing $92 \pm 35.54 \mathrm{~g}$ (approximately $0.1 \mathrm{~kg}$ per replicate) were placed in hermetic containers for $1 \mathrm{~h}$ at $22 \pm 1^{\circ} \mathrm{C} ; 5 \mathrm{~mL}$ of the gaseous atmosphere was then collected from each container (treatment) with a hypodermic syringe to measure the production of ethylene and $\mathrm{CO}_{2}$. Ethylene concentrations were quantified by gas chromatography using a Varian ${ }^{\circledR}$ gas chromatograph, model 3300 ,
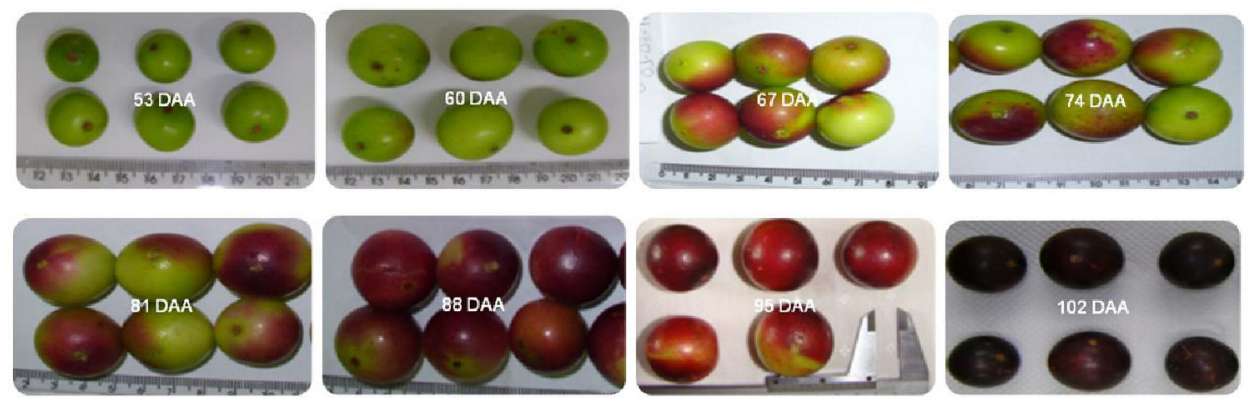

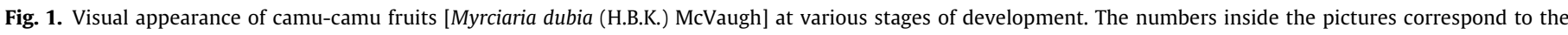
numbers of days after anthesis (DAA). 
equipped with a $1 / 8$ " stainless steel column packed with Porapak ${ }^{\circledR}$ $\mathrm{N}$ and a flame ionization detector. The $\mathrm{CO}_{2}$ concentrations were measured on a Shimadzu ${ }^{\circledR}$ CR 950 chromatograph equipped with a thermal conductivity detection system. Ethylene (100 ppm) and $\mathrm{CO}_{2}(5 \%)$ gases were used as standards. The results were expressed in $\mathrm{mg}$ of $\mathrm{CO}_{2} / \mathrm{kg} \mathrm{h}$ and in $\mu \mathrm{L}$ of ethylene $/ \mathrm{kg} \mathrm{h}$.

\subsection{Total soluble solids (TSS)}

The level of TSS was measured by refractometry on a portable refractometer, with a temperature correction. A drop of pure juice from each of the three replicates containing 30 fruits was measured. The results were expressed in ${ }^{\circ}$ Brix (IAL, 2008).

\subsection{Ratio of total soluble solids (TSS) to titratable acidity (TA)}

The SS/TA ratio was calculated as the ratio of the level of total soluble solids to that of the titratable acidity.

\subsection{Titratable acidity (TA)}

The titratable acidity was measured by diluting $10 \mathrm{~mL}$ of pure juice in $100 \mathrm{~mL}$ of distilled water and titrating this solution with $0.1 \mathrm{M} \mathrm{NaOH}$ to $\mathrm{pH}$ 8.1. The results were expressed in $\mathrm{g}$ of citric acid/100 g of pulp (IAL, 2008).

\subsection{Total and reducing sugars}

The total and reducing sugars were measured according to the method of Nelson (1944), and the results were expressed in $\mathrm{mg}$ of glucose/100 g of pulp. A calibration curve using glucose as the standard was created to calculate the total and reducing sugars.

\subsection{Starch}

One gram of previously lyophilized sample was weighed into a $250 \mathrm{~mL}$ Erlenmeyer flask, and $50 \mathrm{~mL}$ of $1 \mathrm{M} \mathrm{HCl}(8.5 \mathrm{~mL}$ of $\mathrm{HCl}$ in $1 \mathrm{~L}$ of distilled water) was then added to the flask. The flasks were sealed with cotton plugs wrapped in self-adhesive plastic film. The flasks containing the samples were placed in microwave-safe plastic containers that contained sufficient water to prevent the desiccation of the samples. With the flasks inside, the microwave was operated for $20 \mathrm{~min}$ at full power. After this period, during which the starch was converted to sugar, a few drops were removed for testing with Lugol (iodine in potassium iodide, which turns the solution yellow). The sample was then neutralized with $10 \% \mathrm{NaOH}$ $(100 \mathrm{~g} \mathrm{NaOH} / \mathrm{L}$ of water), and three drops of phenolphthalein were added as an indicator (to ensure that the solution remained light pink). Because the sugar in the analyzed sample was not previously separated from the sample, the percentage that corresponds to sugar was subtracted from the measurement to calculate the final starch content (IAL, 2008). The results were expressed in $\mathrm{mg}$ of glucose $/ 100 \mathrm{~g}$ of pulp.

\subsection{Total and soluble pectins}

These compounds were extracted following the procedure described by McCready and McCoomb (1952) and measured colorimetrically by performing acarbazole reaction following the technique described by Bitter and Muir (1962). The total and soluble pectins were expressed as the percentage (\%) of galacturonic acid/100 g of pulp.

\subsection{Pectin methyl esterase (PME) and polygalacturonase (PG)}

Pectin methyl esterase (PME) activity was measured according to the method described by Jen and Robinson (1984). Briefly, we measured the ability of the enzyme to catalyze the demethylation of pectin, i.e., to produce $1 \mu \mathrm{mol}$ of $\mathrm{NaOH}$ per minute under the assay conditions. The results are expressed in $\mu \mathrm{mol}$ of $\mathrm{NaOH} / \mathrm{g}$ min. Polygalacturonase (PG) activity was measured according to the method described by Pressey and Avants (1973). Briefly, we measured the ability of the enzyme to catalyze the formation of $1 \mu \mathrm{mol}$ of reducing sugars per minute per gram of fruit pulp. The results were expressed in U.A.E/g min.

\subsection{Vitamin $C$}

High-performance liquid chromatography (HPLC) analysis was performed to measure the vitamin $\mathrm{C}$ (ascorbic acid) level according to the method described by Campos et al. (2009) using a Shimadzu LC VP HPLC system with a pump (LC-6AD), a UV-VIS detector (SPD10AV VP), and a YMC-Pack ODS column $(250 \times 4.6 \mathrm{~mm}, 5 \mathrm{~mm}$ i.d. $)$. The separation of vitamin $C$ was accomplished by isocratic elution using a phosphoric acid solution at $\mathrm{pH} 3$ as the mobile phase. The UV detector was set at $254 \mathrm{~nm}$. The quantification of the compounds of interest was based on the peak area. The results were expressed in $\mathrm{mg} / 100 \mathrm{~mL}$ of pulp and peel. A $10 \mathrm{~g}$ sample was extracted in $10 \mathrm{~mL}$ of water adjusted to $\mathrm{pH} 1.5$ with $10 \mathrm{~mL}$ of phosphoric acid in water $(2 \% \mathrm{v} / \mathrm{v})$. The extracts were filtered through filter paper, and $1.5 \mathrm{~mL}$ of buffer $\left(0.01 \mathrm{MKH}_{2} \mathrm{PO}_{4}, \mathrm{pH} 8.0\right)$ was added to $1.5 \mathrm{~mL}$ of the filtered sample extract. Subsequently, $1.0 \mathrm{~mL}$ of this mixture was loaded into a C18 cartridge; $3 \mathrm{~mL}$ of water ( $\mathrm{pH} \mathrm{1.5)}$ ) adjusted with $2 \mathrm{~mL}$ of aqueous phosphoric acid $(2 \% \mathrm{v} / \mathrm{v})$ was passed through the cartridges and $20 \mathrm{~mL}$ of eluent was injected into the HPLC. The results were expressed in $\mathrm{mg}$ of ascorbic acid/100 $\mathrm{g}$ of sample on a dry basis (d.b.).

\subsection{Statistical analysis}

A preliminary exploratory analysis of the data was conducted. The data were normally distributed and the errors were independent and exhibited homoscedasticity. The design was completely randomized with a factorial scheme only for vitamin $C$ analysis (seven harvest times $\times$ two sample types (pulp and peel,). Three replicates of 10 fruits analyzed used for the physical analyses, while three replicates of 30 fruits were analyzed for the chemical analyses. Data were subjected to an analyses of variance (ANOVA), and the means were compared by Tukey's multiple range test and least significant differences (LSD) at ${ }^{*} P \leq 0.05$. All statistical analyses were performed using the SISVAR - UFLA program, version 5.1 .

\section{Results and discussion}

All data presented here represent the means of six seasons (years) of study.

\subsection{Fresh weight and polar and equatorial diameters of fruits}

In a natural habitat, the camu-camu develops over a 102-day period of full flowering and ripening. The fresh weights of the camucamu fruits increased between 53 and 81 days after anthesis (DAA) and declined thereafter; the weight of these fruits peaked at $12 \mathrm{~g}$ (Fig. 2).

Thus, the developmental period of the fruit was characterized by an initial period of rapid growth that lasted until 60 DAA; during this time, the weight of the fruits tripled from an initial weight of $2.11 \mathrm{~g}$ to a mean fresh weight of $6.89 \mathrm{~g}$. This increase corresponds 


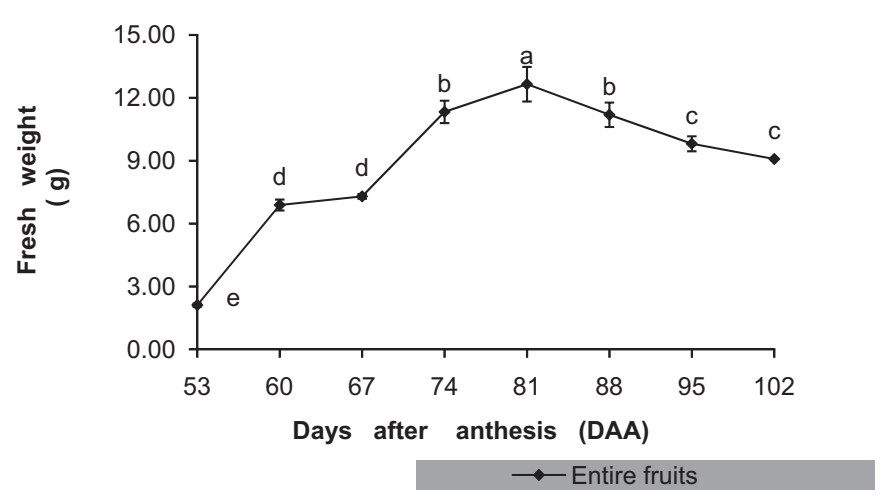

Fig. 2. Fresh weights (g) of camu-camu (Myrciaria dubia) fruit during development from 53 to $102 \mathrm{DAA}$

to a growth rate of $683.00 \mathrm{mg} /$ day. The fruits were still green (i.e., immature) during these initial two evaluation periods (Table 1).

From 67 to 81 DAA, the fruits gained weight at a slower rate, and the peel began to turn red; at the end of this period (81 DAA), the fresh weight reach the maximum, and $50 \%$ of the peel area of these fruits had acquired a reddish color (Table 1 and Fig. 1). These results suggest that the fruit reached physiological maturity 81 DAA and ripened during the subsequent period.

Fruit growth ceased by 81 DAA, and the mean weight of the fruits declined until 88 DAA because of fruit transpiration (loss of turgor) associated with the high insolation and evaporation characteristics of the Amazon region and the onset of ripening and senescence. A similar pattern of growth has been reported for 'Haden' Mangos: these fruits attained their maximum fresh weight 55 days after flowering (DAF) (in a cycle lasting from 15 to 73 DAF) and exhibited fresh weight decreases and water losses thereafter (Castro Neto and Reinhardt, 2003). 'Obatã' coffee fruits also exhibited losses in fresh weight and volume after the growth phase (Cunha and Volpe, 2011).

The color of the fruits began to change from red (85\% red) at 88 DAA to purple (100\% purple 102 DAA). This change supposedly reflects ripening and the onset of senescence. Yuyama et al. (2002) has described ripened fruits as being purplish or almost black, slightly dehydrated, and shriveled.

Following a similar pattern as the fruit fresh weight, the equatorial and polar diameters of the camu-camu fruit increased until 81 DAA and then decreased (Fig. 3) because of a loss of turgor.

The growth in the diameters of the fruits was proportional to the gain in fresh weight and was characterized by higher growth rates during the initial evaluation period and a deceleration and stabilization of the growth by 81 DAA.

Table 1

Color of the peel of camu-camu fruit during development.

\begin{tabular}{ll}
\hline Days of anthesis (DAA) & Peel color \\
\hline 53 DAA & $\begin{array}{l}100 \% \text { green } \\
100 \% \text { green }\end{array}$ \\
60 DAA & $\begin{array}{l}90 \% \text { green with slight reddish } \\
\text { coloration on the side exposed } \\
\text { to the sun }\end{array}$ \\
& $75 \%$ green with slight reddish \\
& coloration on the side exposed \\
& to the sun \\
& $50 \%$ green and $50 \%$ red on the \\
& side exposed to the sun \\
81 DAA & $85 \%$ red with some light green \\
& on the side not exposed to the \\
sun & $100 \%$ red \\
& $100 \%$ dark red to purple \\
\hline
\end{tabular}

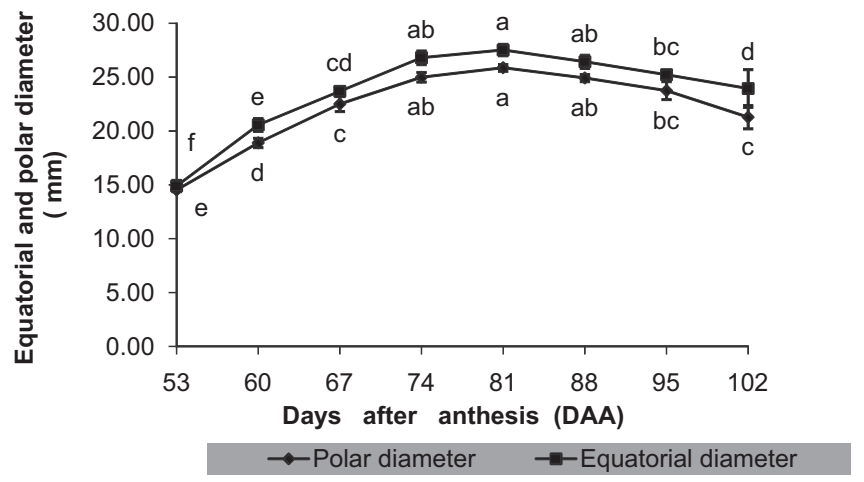

Fig. 3. Equatorial and polar diameters ( $\mathrm{mm}$ ) of camu-camu (Myrciaria dubia) fruit during development from 53 to 102 DAA.

The patterns of growth for the polar and the equatorial diameters were similar (Fig. 3); however, the growth of the equatorial diameter exceeded that of the polar diameter during the development and ripening of the fruits. This finding suggests that the width of the fruit is greater than the length, which is a defining characteristic of the sub globose shape of the camu-camu. Alves et al. (2002) reported that fruits harvested from the experimental station of Embrapa Amazônia East had a similar sub globose shape, with a mean equatorial diameter ranging from 22.31 to $23.06 \mathrm{~mm}$ and a mean polar diameter ranging from 21.44 to $22.11 \mathrm{~mm}$ in the fully green and fully red stages, respectively. The equatorial diameters of the camu-camu fruits analyzed in the present study were greater than the equatorial diameters of camu-camu fruits from Mirandópolis (21.7-24 mm) and Iguape (São Paulo) (22.31-23.06 mm) (Zanatta et al., 2005). These findings suggest that the soil and climatic characteristics of the Amazon are favorable for the rapid growth and high yield of camu-camu fruit.

\subsection{Respiration and ethylene production}

The mean respiratory rate of the camu-camu ranged from 10.00 to $20.00 \mathrm{mg} \mathrm{CO}_{2} / \mathrm{kg} \mathrm{h}$, which corresponds to an intermediate respiration rate (Kader, 2002). The respiration rate of camu-camu fruits decreased throughout fruit development (Fig. 4).

The largest amounts of $\mathrm{CO}_{2}$ were produced during the first evaluation periods $(53,60$, and 67 DAA) because of the high metabolism associated with initial fruit development during these periods (Payasi and Sanwal, 2010). Steady decreases in $\mathrm{CO}_{2}$ production were observed during the subsequent periods, and there was no detectable respiration after 81 DAA, when the fruits had reached physiological maturity. In a study of camu-camu fruits in
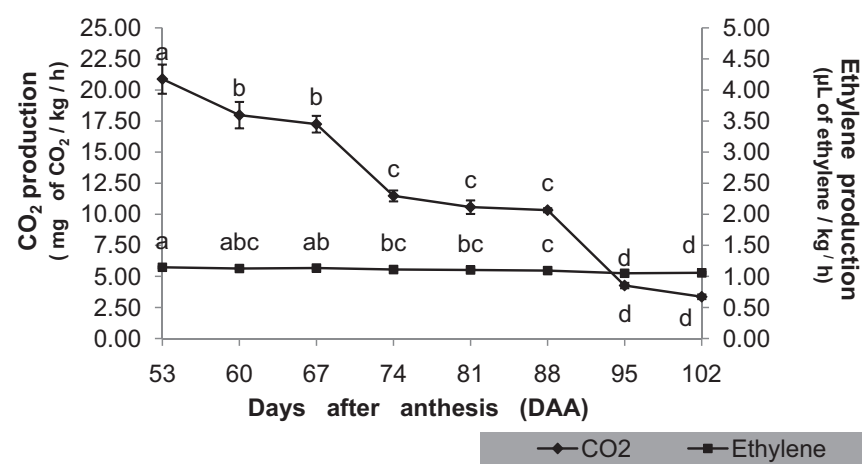

Fig. 4. Production of $\mathrm{CO}_{2}$ and ethylene in camu-camu (Myrciaria dubia) fruit during development from 53 to 102 DAA. 

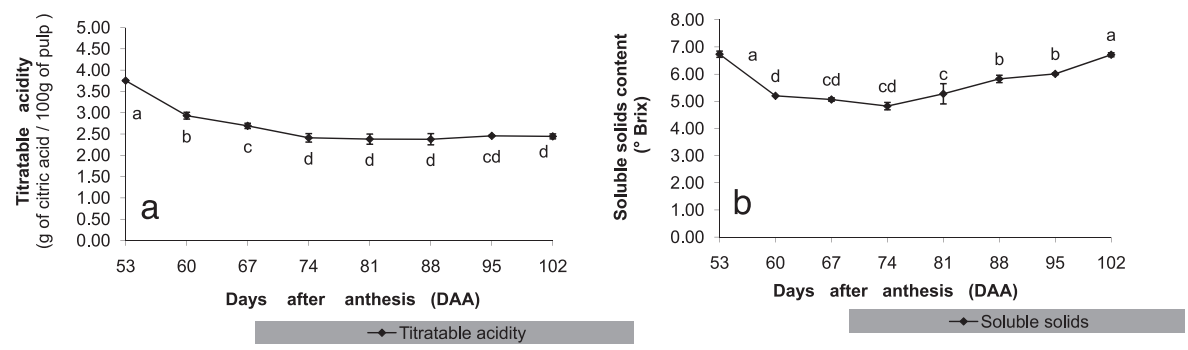

Fig. 5. Titratable acidity (5.1) and soluble solids content (5.2) of camu-camu fruit during development from 53 to 102 DAA

the Colombian Amazon conducted from anthesis to full maturity by Bardales et al. (2008), a similar pattern was observed, also characterized by no respiratory peak and the maintenance of moderate respiratory rates until the end of the experiment, contradicting the results presented by Pinto et al. (2013). The Camu-camu fruit is considered to be a non-climacteric fruit because of the lack of a respiratory peak before and/or during ripening, (Payasi and Sanwal, 2010). In this regard, by $95 \mathrm{DAA}, \mathrm{CO}_{2}$ production decreased to below $5.00 \mathrm{mg} \mathrm{CO} 2 / \mathrm{kg} \mathrm{h}$, possibly because of the late harvest time and the senescence process of the fruits.

The camu-camu fruit is also considered non-climacteric because of its low and invariable production of ethylene during development and ripening (Fig. 4). Our data support the findings of Bardales et al. (2008), who compared the respiratory rates of various nonclimacteric species of the Myrtaceae family and determined that camu-camu was characterized by a moderate respiratory rate, no detectable climacteric peak, and considerable ethylene production during development. Other authors (Pinedo et al., 2011; Andrade et al., 2010) who have conducted studies of camu-camu fruits cultivated in the Amazon region have also presented results that suggest non-climacteric behavior for the camu-camu fruit.

According to Pinto et al. (2013), camu-camu fruits were considered to be climacteric because fruits that were harvested while unripe (stage 1 ) could exhibit climacteric and ethylene production peaks after harvest. However, despite these characteristics, these fruits did not develop several of the quality attributes expected for climacteric fruits, and these attributes were only observed in fruits harvested at more advanced maturation stages. Thus, based on these conditions, the results obtained by these authors can be considered as contradictory because unripe fruits that are classified as climacteric should develop all quality attributes, also exhibited by ripe fruits. So, either the fruits were harvested too early, or they exhibited a non-climacteric pattern, given that post-flowering or post-anthesis monitoring was not performed to determine the developmental stage at which the fruits were harvested. According to Fonseca et al. (2002), the maturation stage usually influences the level of respiratory activity. Thus, very unripe or non-climacteric fruits exhibit accelerated metabolism and high respiratory activity. When removed from the parent plant, these fruits tend towards senescence rather than maturation.

In turn, Bardales et al. (2008) monitored the development of camu-camu fruits from the full flowering stage until fruit ripening. These authors found that the fruits exhibited high respiration rates during the initial stages of development, with this rate decreasing after the fruits reached their maximum growth and remaining at a moderate level of approximately $100 \mathrm{mg}$ of $\mathrm{CO}_{2} / \mathrm{kg}$ h or less during ripening. Furthermore, in that study, the pattern of ethylene production during ripening was compatible with a non-climacteric pattern, a result that confirms that the respiratory pattern of camucamu is similar to that of other non-climacteric species of the family Myrtaceae.

However, in camu-camu fruits cultivated in the São Paulo region, where the soil and climatic characteristics differ from those of the
Amazon, Pinto et al. (2013) detected a climacteric behavior for the camu-camu fruits grown in an upland area. Nevertheless, in the present study, the fruits were harvested in their native region, characterized by seasonal flooding, based on temporal criteria. In addition, using a subjective parameter (such as the skin color) to determine the harvest time may cause the producer to make an incorrect decision regarding the optimal harvest time because of the inherent color variation in the fruit (especially for a nondomesticated species), even at the (supposedly) same maturity stage. Wills et al. (1998) also reported that the respiration rate decreases in non-climacteric fruits during ripening and that the biochemical transformations responsible for ripening occur more slowly. Therefore, unlike climacteric fruits, which have the ability to ripen after harvest, non-climacteric fruits (such as the camucamu) only ripen when attached to the plant (Payasi and Sanwal, 2010).

\subsection{Titratable acidity (TA), total soluble solids (TSS), and TSS/TA ratio}

The titratable acidity of the camu-camu fruits decreased until 88 DAA to a minimum of $2.28 \mathrm{~g}$ of citric acid/100 $\mathrm{g}$ and then increased slightly but non-significantly at 95 and 102 DAA (Fig. 5).

The decrease in TA can be explained by the use of organic acids in respiration and as a result of a dilution effect occurring during fruit growth (Prassana et al., 2007). The small increase in TA during the final two collection periods (95 and 102 DAA) was associated with the loss of moisture in the fruit and the consequent concentration of the acids in the cellular fluid. This pattern is consistent with previous findings that completely green fruits have high TA, and completely red fruits have relatively low TA (Alves et al., 2002; Pinto et al., 2013).

The TSS content of the camu-camu fruits decreased to a minimum of $5.00^{\circ}$ Brix at 74 DAA and then increased from 81 to 102 DAA to a final value of $6.71^{\circ} \mathrm{Brix}$ (Fig. 5.2). The decrease in the first stage of fruit development may have occurred because sugars were used to form structural polysaccharides (Rossetto et al., 2004) and components of cell walls. The increase in TSS content that began 81 DAA resulted from increases in the reducing sugars associated with the onset of maturation. Camu-camu fruits at green and reddish-green stages (unripe) also contained lower total soluble solids compared to those at red-greenish or purple stages, which are considered fully ripe fruits in the study by Pinto et al. (2013).

However, in the case of the camu-camu, organic acids also contribute to the increase in TSS (Alves et al., 2002). Thus, the increase in TA during the final two periods may have also contributed to the increase in TSS. Alves et al. (2002) detected no significant differences in the TSS contents of completely green and completely red fruits. We also failed to detect significant differences between the TSS contents of camu-camu fruits at 53 DAA and 102 DAA (Fig. 5.2).

The TSS contents of the fruits increased when the fruits began to acquire a completely red peel (i.e., at the onset of fruit ripening). Thus, 81 DAA appears to mark the end of physiological maturity 


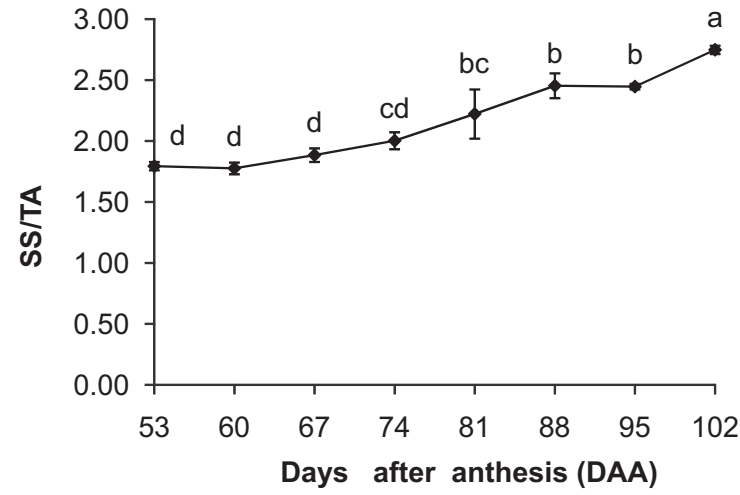

SS/TA

Fig. 6. Ratio of total soluble solids to titratable acidity (TSS/TA) in camu-camu fruit (Myrciaria dubia) during development from 53 to 102 DAA.

and the onset of ripening, and the TSS contents of the fruit differed significantly in the two harvest periods following this transition period. It can thus be inferred that TSS can be used to measure the degree of maturity of ripening camu-camu fruits. For camucamu fruits, an association between the SS and the color of the peel should not be ruled out; indeed, when the fruit was completely purple (102 DAA), the TSS content of the fruit was greatest. The pulp of the camu-camu fruit became sweeter and less acidic as ripening advanced. Therefore, the ripening period represents an ideal harvest time for the in natura consumption of this fruit or the processing of fruit for derivatives such as jams and jellies.

Because the TSS contents and the TA were inversely related during maturation, the TSS/TA ratio exhibited a positive linear increase (Fig. 6).

This ratio is an important qualitative attribute because it indicates the relative contributions of the compounds responsible for sweetness and acidity, respectively, and therefore provides an indication of the flavor of the fruit (Prassana et al., 2007).

In addition, this ratio is considered a marker of the maturation stage of fruit that can predict the sweetness of the fruit. Stenzel et al. (2006) also observed a positive linear progression in the TSS/TA ratio of fruits of 'Folha Murcha' orange trees grafted on various varieties of stocks from two distinct regions; these authors used this ratio to estimate the ideal harvest time. The TSS/TA ratio can also be used to assess the degree of maturation of the camu-camu. The TSS/TA ratios observed in our study were relatively low, ranging from 1.79 at 53 DAA to 2.75 at 102 DAA, indicating that the camucamu fruit is not as sweet as other fruits such as the 'Paluma' guava (TSS/TA ratios ranging from 9.88 to 17.66) (Cavalini et al., 2006) or the 'Dixie' grape (SS/TA ratios ranging from 0.51 to 6.88 ) (Sachi and Biasi, 2008). This ratio also confirms that the camu-camu fruit has an acidic flavor, even during ripening. This acidity limits the consumption of this species in natura and favors the dilution and use of this fruit for the processing for derivatives such as jams, juices, and ice cream, which can add value to this fruit.

\subsection{Total sugars, reducing sugars and starch}

The total and reducing sugars increased during the development of the camu-camu fruit, with a more pronounced accumulation of reducing sugars (Fig. 7.1).

The increase in the total and reducing sugars coincided with the increases in the fresh weight and diameter of the fruits; this period represents the period when the fruits are nearly ripe and, consequently, the ideal harvest time. The concentration of total sugars peaked at $1.68 \mathrm{mg}$ glucose $/ 100 \mathrm{~g}$ of sample at 88 DAA and then declined during the ripening process as these sugars were metabolized. An increase in total sugar during the transition from the green stage to the fully red stage was also reported by Alves et al. (2002). The breakdown of sugars also resulted in an increase in the reducing sugars to a maximum of $0.95 \mathrm{mg}$ glucose $/ 100 \mathrm{~g}$ at 102 DAA. This period was considered to represent the period when the fruit was most mature and when fruit senescence began. The production of total and reducing sugars peaked in jabuticaba fruit at 55 DAA (i.e., during the period of fruit ripening) and decreased in subsequent periods when these sugars were used for respiratory processes (Corrêa et al., 2007). Such decreases in sugar were not observed in the camu-camu because the respiratory rate decreased during the final periods of fruit ripening.

The sugar patterns suggest that the synthesis of sugars (especially reducing sugars) was low during the initial period of fruit development until 67 DAA. The increased sugars in subsequent harvests coincided with steadily declining starch contents (Fig. 7.2). Alves et al. (2002) also reported a decrease in the starch content of mature camu-camu fruits. In contrast, the starch content, but not the sugar, of jabuticaba decreased from 25 DAA until 50 DAA (Araújo et al., 2010). The reducing sugars fructose and glucose come from the degradation of sucrose and polysaccharide reserves such as starch (Prassana et al., 2007). Thus, a lower starch content and higher level of reducing sugars is associated with a more advanced stage of fruit ripening. Although the reducing sugars increased during fruit development after 81 DAA, they remained high and relatively stable until 102 DAA, in contrast to the starch contents. Therefore, the starch contents could also be used to estimate the degree of maturity of camu-camu fruits and to determine the ideal harvest time of non-climacteric fruits such as the camu-camu.

\subsection{Total and soluble pectins and pectic enzymes}

The degradation of cell wall polysaccharides, which is measured by the total and soluble pectins, may have contributed to the changes in the reducing sugars (Fig. 8.1).

The concentration of total pectins tended to decrease in a linear manner; this finding confirms that the first experimental harvests $(53,60$, and 67 DAA) coincided with the fruit's stages of
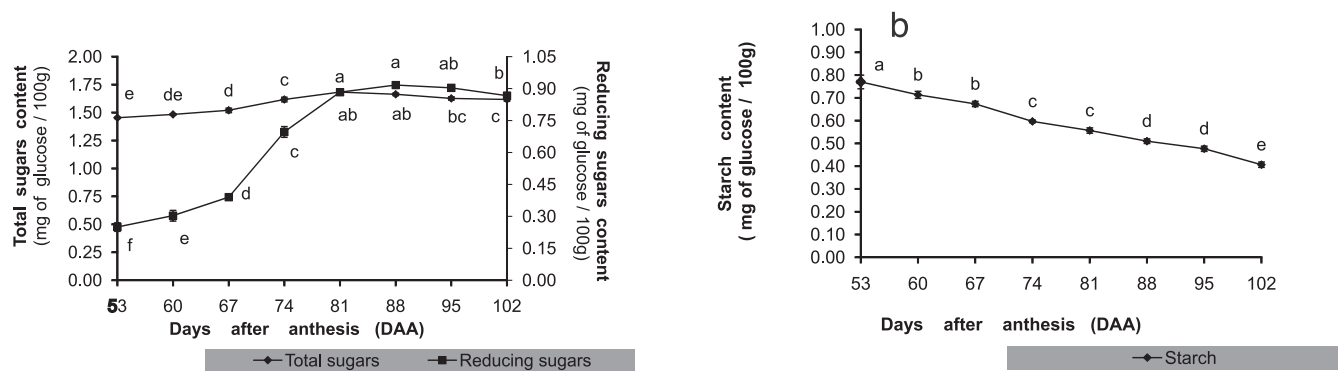

Fig. 7. Total and reducing sugars (7.1) and starch (7.2) in camu-camu (Myrciaria dubia) fruit during development from 53 to 102 DAA. 

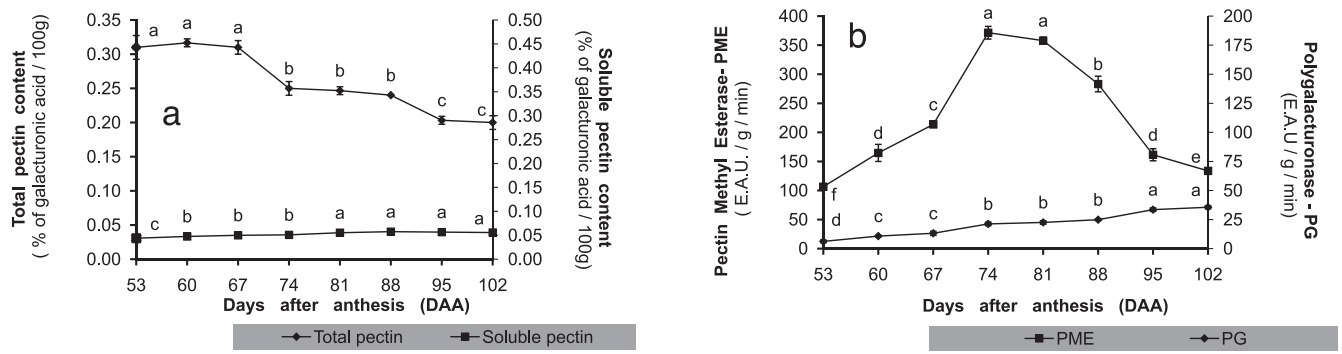

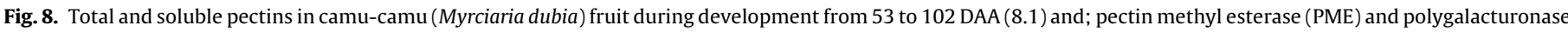
(PG) enzyme activity in camu-camu (Myrciaria dubia) fruit during development from 53 to 102 DAA (8.2).

physical growth during which the total pectin were high because they contribute to the structure of young cells and tissues. During subsequent harvests, the depolymerization and consequent solubilization of pectins, together with other chemical changes, solubilized the protopectin fraction, as evidenced by the steady decline in total pectin and the slight increase in soluble pectin (Fig. 8.1). The increased of soluble pectins were a marker of the solubilization of pectins from the cell wall and the resultant structural loss of cellular tissues; Araújo et al. (2010) have noted similar findings. Alves et al. (2002) have also reported decreases in the total pectins and a non-significant increase in soluble pectin in the camu-camu during the transition from the fully green to the fully red stage. According to Araújo et al. (2010), the soluble pectin in the pulp and peel of jabuticaba also tend to increase with maturation.

Depolymerization occurred to the greatest extent during the period beginning $74 \mathrm{DAA}$; at this time, the activity of pectin methyl esterase (PME) also peaked and the activity of polygalacturonase (PG) began to increase. This period presumably corresponds to the onset of the cell wall degradation process and the consequent physical changes in the fruit (Fig. 8.2). This result confirms that the onset of ripening, which is marked by enhanced enzymatic activity in the camu-camu, occurs when the fruit begins to take a reddish coloration, as shown in Table 1. After this period, the activity of PME and PG steadily decreased and increased, respectively, until 102 DAA. A similar pattern occurred for the demethylation of polymers of galacturonic acid, which is initially triggered by PME, and the subsequent cleavage of these polymers by PG (Prassana et al., 2007). The activities of PME and PG in the present study were similar to those reported by Alves et al. (2002), who determined that PME activity was significantly higher than PG activity in green fruits and that PG activity were more pronounced in mature red fruits. These changes in the solubility of pectins during ripening are associated with the depolymerization of pectic chains and may lead to changes in the external appearance of the fruit.

\subsection{Vitamin $C$}

The pulp and the peel of camu-camu fruits were worked, presented high vitamin C (Fig. 9).

The maturation phase was characterized by the accumulation of ascorbic acid and a higher rate of synthesis. During this phase, the volume of the fruits peaks, and the ripening and biochemical reactions that result in changes in the sensory compounds of fruits (which make the fruits edible) are initiated (Giovannoni, 2004). Synthesis activities peaked at 88 DAA (i.e., at the onset of ripening) when the fruits had also accumulated the greatest amount of ascorbic acid (4752.23 and $5178.49 \mathrm{mg}$ of ascorbic acid/100 $\mathrm{g}$ of sample in the pulp and peel, respectively). At the subsequent harvests, the ascorbic acid contents decreased in both fractions, most likely because of the onset of catabolic reactions promoted by fruit ripening. Similar results were also reported by Villanueva-Tiburcio et al. (2010).).
A number of studies have reported increases in ascorbic acid during the maturation and ripening of the camu-camu fruit. Zapata and Dufour (1993) reported an increase from 8.64 g of ascorbic acid $/ \mathrm{kg}$ of fruit in unripe fruits to $9.70 \mathrm{~g}$ of ascorbic acid $/ \mathrm{kg}$ of fruit in completely red and fully ripe fruits. Andrade et al. (1995) measured the variation in vitamin $C$ content during the development and six stages of maturation of the camu-camu fruit and reported that vitamin $C$ accumulated in the fruit from maturation stage 3 to the final stage (from 2004.66 to $2605.76 \mathrm{mg}$ of ascorbic acid/100 $\mathrm{g}$ of fruit). Alves et al. (2002) also measured higher ascorbic acid in red fruits (up to $2061.04 \mathrm{mg}$ of ascorbic acid/100 $\mathrm{g}$ of sample) than in green fruits (1910.31 mg of ascorbic acid/100 g of sample) and reported that the mature camu-camu had higher vitamin $C$ than other vitamin C-rich fruits, such as the acerola. Yuyama et al. (2011) also determined that redder camu-camu fruits have higher vitamin C. In contrast, we found that younger fruits (88 DAA) had higher concentrations of vitamin $C$ than fully ripened fruits (102 DAA). Other studies have also reported decreases in ascorbic acid in more mature camu-camu fruits. Chirinos et al. (2010) reported that completely green fruits had higher concentrations of ascorbic acid than completely red fruits. Smiderle and Sousa (2008) reported that unripe and ripe fruits had 2520.00 and $2590.00 \mathrm{mg} / 100 \mathrm{~g}$ of vitamin $\mathrm{C}$ in the samples, respectively, and concluded that fruits at these two stages of maturity did not have significantly difference in the vitamin C. Consistent with the results of our study, Correa et al. (2011) measured vitamin $C$ in both the peel and pulp of ripening camucamu fruits (also by HPLC) and found that vitamin C decreased as the fruit ripened. Villanueva-Tiburcio et al. (2010) analyzed camucamu peels on a dry basis and found that fruits in an intermediate stage of ripening had higher ascorbic acid $(53.49 \pm 9.40 \mathrm{mg}$ ascorbic acid/g d.b.) than fully ripe fruits ( $16.41 \pm 3.64 \mathrm{mg}$ ascorbic acid $/ \mathrm{g}$ d.b.) and completely green fruits $(15.38 \pm 5.81 \mathrm{mg}$ ascorbic acid $/ \mathrm{g}$ d.b.); however, the ascorbic acid in these fully ripe and green fruits did not differ significantly. In the present study, fruits at an intermediate stage of maturation or that had just begun to ripen ( 88 DAA) also showed relatively high ascorbic acid that decreased in

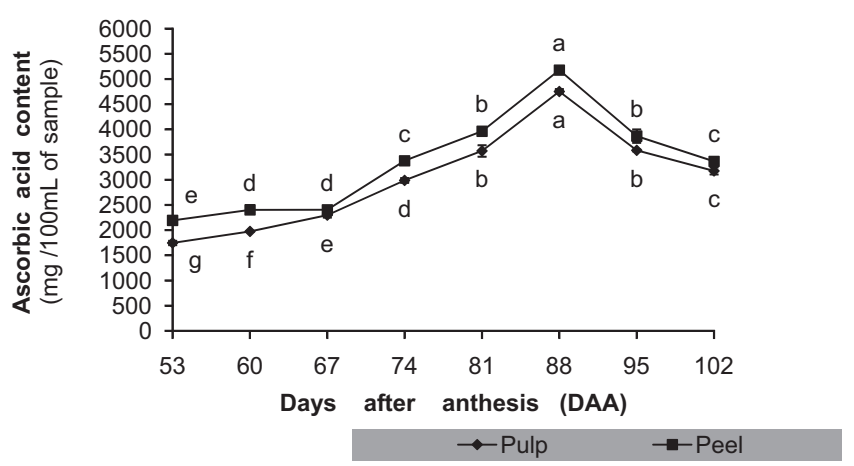

Fig. 9. Ascorbic acid in the samples of pulp and peel (lyophilized) of camu-camu (Myrciaria dubia) fruit during development from 53 to 102 DAA. 
subsequent periods (Fig. 9). Villachica (1996) also reported that $100 \%$ green, $100 \%$ ripe, and over-ripened fruit had $17 \%, 9 \%$, and $20 \%$ less ascorbic acid, respectively, than fruits at an intermediate stage of ripening (75\% ripe based on peel coloration). This author concluded that fruits used to produce ascorbic acid can be harvested at the green stage after reaching physiological maturity or at an intermediate stage of maturity, when the vitamin $C$ peak.

Similar to this study, Bardales et al. (2008) also observed a higher ascorbic acid content at the intermediate stage of maturation, which presented a maximum content of $2900 \mathrm{mg} / 100 \mathrm{~g}$, while the green and mature fruits contained approximately $2100 \mathrm{mg} / 100 \mathrm{~g}$. In contrast, Pinto et al. (2013) reported higher ascorbic acid content in camu-camu fruits during full maturation $(1071.12 \mathrm{mg} / 100 \mathrm{~g}$ ), and Rodrigues et al. (2001) measured a maximum content when camu-camu fruits were green.

Large variations in vitamin C, attributed primarily to genetic differences, have been described in various populations of camu-camu fruits. Analyzes of isozymes (esterase and esterase-D) isolated from camu-camu populations in Iquitos (Peru), Uatumã (Amazonas), and Boa Vista (Roraima) suggests that these differences in vitamin C are genetic in origin (Teixeira et al., 2004). However, differences in environmental conditions (e.g., soil and climatic variations) can also affect the vitamin $\mathrm{C}$ content of camu-camu fruit (Justi et al., 2000). According to Correa et al. (2011), the ascorbic acid concentration of the camu-camu decreases as the fruit ripens because of the action of enzymes such as ascorbate oxidase, phenolase, and cytochrome oxidase.

The peel had the highest ascorbic acid during the development of the camu-camu (Fig. 8). Correa et al. (2011) similarly reported that the level of ascorbic acid in the peel of the camu-camu was $28 \%$ higher than that of the pulp and remained high at all stages of ripening. Pinedo et al. (2011) argued that the increase in the ascorbic acid level of the peel results from a greater exposure of the fruit to sunlight, which favors photosynthesis and the production of carbohydrates that are metabolized to ascorbic acid.

\section{Conclusion}

Under the conditions tested, the best harvest time for the camucamu fruit occurred between 88 and 95 days. During this period, measured parameters such as the color ( $85 \%$ and $100 \%$ red), the high TSS/TA ratio, the low TA, the high TSS and reducing sugars, and the high contents of soluble pectins and vitamin $C$ achieved their optimal. Based on these results, it can be assumed that fruits harvested between 88 and 102 DAA will taste better than fruits harvested earlier or later than this time range.

To obtain the highest vitamin $\mathrm{C}$, the fruit should be harvested when it is approximately $85 \%$ red (88 DAA). However, if the fruit is to be consumed in natura, it should be harvested 102 DAA ( $100 \%$ purple peel), when it is fully mature. At this stage, the SS and the $\mathrm{TA} / \mathrm{SS}$ ratio were greatest under the conditions tested in this study.

\section{References}

Alves, R.E., Filgueiras, H.A.C., Moura, C.F.H., Araújo, N.C.C., Almeida, A.S., 2002. Camucamu [(Myrciaria dubia (H.B.K.) McVaugh]: a rich natural source of vitamin C. Proc. Int. Soc. Trop. Hortic. 46, 11-13.

Andrade, J.S., Aragão, C.G., Galeazzi, M.A.M., Ferreira, S.A.N., 1995. Changes in the concentration of total vitamin C during maturation of camu-camu [(Myrciaria dubia (H.B.K.) McVaugh] fruits cultivated in the upland of Brazilian Central Amazon. Acta Hortic. 370, 177-180.

Andrade, J.S., Silveira, J.S., Ferreira, S.A.N., Brasil, J.E.B., 2010. Effects of ripening stage and environmental conditions on stored postharvest camu-camu (Myrciaria dubia Mc Vaugh) fruits. Acta Hortic. 864, 423-429.

Araújo, F.M.M.C., Machado, A.V., Lima, H.C., Chitarra, A.B., 2010. Physical and chemical changes in the jabuticaba fruit (Myrciaria jaboticaba berg cv. Sabará) during development. Rev. Verde 5, 109-116.

Bardales, X.I., Carrillo, M.P., Hernandez, M.S., Barrera, J.A., Fernandez-Trujillo, J.P., Martinez, O., 2008. Camu-camu fruit (Myrciaria dubia), a new option for productive systems in the Colombian Amazonian region. Acta Hortic. 773, 173-178 (The Hague).

Bitter, T., Muir, H.M., 1962. A modified uronic acid carbazolereaction. Anal. Biochem. 34, 330-334.

Campos, F.M., Ribeiro, S.M.R., Della Lucia, C.M., Stringheta, P.C., Pinheiro-Sant'Ana H.M., 2009. Optimization of methodology to analyze ascorbic acid and dehydroascorbic acid in vegetables. Quím. Nova 32, 87-91.

Castro Neto, M.T., Reinhardt, D.H., 2003. Relations hips between growth parameters in the mango cv Haden fruit. Rev. Bras. Frutic. 25, 36-38.

Cavalini, F.C., Jacomino, A.P., Lochoski, M.A., Kluge, R.A., Ortega, E.M.M., 2006. Maturity indexes for kumagai and paluma guavas. Rev. Bras. Frutic. 28, 176-179.

Chirinos, R., Galarza, J., Betalleluz-Pallardel, I., Pedreschi, J., Campos, D., 2010. Antioxidant compounds and antioxidant capacity of Peruvian camu-camu (Myrciariadubia (H.B.K.) McVaugh) fruit at different maturity stages. Food Chem. 120, 1019-1024.

Corrêa, M.O.G., Pinto, D.D., Ono, E.O., 2007. Analysis of respiratory activity in jabuticaba fruits. Rev. Bras. Biociênc. 5, 831-833.

Correa, S.I., Zamudio, L.B., Solis, V.S., Cruz, C.O., 2011. Vitamin C content of camucamu Myrciaria dubia (HBK) Mc Vaugh fruit at four stages of maturation from the Collection INIA Germplasm Loreto. Peru. Rev. Sci. Agropecu. 02, 123-130.

Cunha, A.R., Volpe, C.A., 2011. Growth curves for the fruit of coffee cv. Obatã IAC 1669-20 in different planting arrangements. Rev. Semin.: Ciênc. Agrár. 32, 49-62.

Fonseca, S.C., Oliveira, F.A.R., Brecht, J.K., 2002. Modelling respiration rate of fresh fruits and vegetables for modified atmosphere packages: a review. J. Food Eng. $52,99-119$.

Giovannoni, J.J., 2004. Genetic regulation of fruit development and ripening. Plant Cell 16, 170-180.

Instituto Adolfo Lutz [IAL], 2008. Physicochemical Methods for Food Analysis. IAL, São Paulo, SP, Brasil.

Jen, J.J., Robinson, M.L.P., 1984. Pectolytic enzymes in sweet bell peppers (Capsicum annum L.). J. Food Sci. 49, 1085-1087.

Justi, K.C., Visentainer, J.V., Souza, N.E., Matsushita, M., 2000. Nutritional composition and vitamin C stability in stored camu-camu (Myrciaria dubia) pulp. Arch. Latinoam. Nutr. 50, 405-408.

Kader, A.A., 2002. Postharvest biology and technology: an overview. In: Karder A.A. (Ed.), Postharvest Technology of Horticultural Crops. , 3 ed. University of California, California, pp. 435-461.

McCready, P.M., McCoomb, E.A., 1952. Extraction and determination of total pectic material. Anal. Chem. 24, 1586-1588.

Nelson, N.A., 1944. Photometric adaptation of the Somogy method for the determination of glucose. J. Biol. Chem. 153, 375-380.

Payasi, A., Sanwal, G.G., 2010. Ripening of climacteric fruits and their control. J. Food Biochem. 34, 679-710.

Pinedo, S., Iman, S., Pinedo, M., Vasquez, A., Collazos, H., 2011. Clonal trial of five genotypes of "camu-camu", Myrciaria dubia (H.B.K) Mc. Vaugh, in non-flooded area. Afr. J. Plant Sci. 5, 40-46.

Pinto, P.M., Jacomino, A.P., Silva, S.R., Andrade, C.A.W., 2013. Harvest point and maturation of camu-camu fruit harvested at different stages. Pesqui. Agropecu. Bras. 48, 605-612.

Prassana, V., Prabha, T.N., Tharanathan, R.N., 2007. Fruit ripening phenomena-an overview. Crit Rev. Food Sci. Nutr. 47, 1-19.

Prill, M.A.S., Neves, L.C., Chagas, E.A., Tosin, G.M., Silva, S.S., 2012. Methods for acclimating 'prata-anã' bananas produced in the Northern Brazilian Amazon. Rev. Bras. Frutic. 34, 990-1003.

Pressey, R., Avants, J.K., 1973. Separation and characterization of exopolygalacturonase and endopolygalacturonase from peaches. Plant Phisiol. 52, 252-256.

Rodrigues, R.B., Menezes, H.C., Cabral, L.M.C., Dornier, M., Reynes, M., 2001. An Amazonian fruit with a high potential as a natural source of vitamin C: the camu-camu (Myrciaria dubia). Fruits 56, 345-354.

Rossetto, M.R.M., Purgatto, E., Lajolo, F.M., Cordenunsi, B.R., 2004. Influence of gibberellic acid in the breakdown of starch during banana ripening. Ciênc. Tecnol. Aliment. 24, 76-81.

Sachi, A.T., Biasi, L.A., 2008. Fruit ripening of four cultivars of muscadine grapes in Pinhais, PR. Sci. Agrar. 9, 255-260.

Smiderle, O.J., Sousa, R.C.P., 2008. Vitamin C content and physical characteristics of the camu-camu at two stages of maturation. Rev. Agro@mbiente On-line 2, 61-63.

Stenzel, N.M.C., Neves, C.S.V.J., Marur, C.J., Scholz, M.B.S., Gomes, J.C., 2006. Maturation curves and degree-day accumulations for fruits of 'folhamurcha' orange trees. Sci. Agric. 63, 219-225.

Teixeira, A.S., Chaves, L. da Silva., Yuyama, K., 2004. Esterases for examining the population structure of Camu-camu [Myrciaria dubia (Kunth) (McVaugh) Myrtaceae]. Acta Amazôn. 34, 75-88.

Villachica, H., 1996. Cultivation of the camu-camu in the Peruvian Amazon (E cultivo del camu-camuen la Amazonia Peruana.) Secretaría Pro Tempore del Tratado de Cooperación Amazónica-Lima/Peru. 〈http://www.siamazonia. org.pe/archivos/publicaciones/amazonia/libros/46/base.htm/) (accessed 13.02.12.).

Villanueva-Tiburcio, J.E., Condezo-Hoyos, L.A., Asquieri, E.R., 2010. Anthocyanins, ascorbic acid, total polyphenols and antioxidant activity in camu-camu (Myrciaria dubia (HBK) McVaugh) peels. Ciênc Tecnol. Aliment. Camp. 30, $151-160$.

Wills, R., McGlasson, B., Graham, D., Joyce, D., 1998. Postharvest: An Introduction to the Physiology and Handling of Fruit, Vegetables and Ornamentals. CAB International, New York. 
Yuyama, K., Yuyama, L.K.O., Aguiar, J.P.L., 2011. Harvesting, processing, transportation and marketing. In: Yuyama, K., Valente, J.P. (Eds.), Camu-Camu. CRV, Curitiba, pp. 119-123.

Yuyama, K., Aguiar, J.P.L., Yuyama, L.K.O., 2002. Camu-camu: a fantastic fruit source of vitamin C. Acta Amazôn 32, 169-174.
Zanatta, C.F., Cuevas, E., Bobbio, F.O., Winterhalter, P., Mercadante, A.Z., 2005. Determination of Anthocyanins from camu-camu (Myrciaria dubia) by HPLC-PDA HPLC-MS, and NMR. J. Agric. Food Chem. 53, 9531-9535.

Zapata, S.M., Dufour, J., 1993. Camu-camu, Myrciaria dubia (HBK) McVaugh: chemica composition of fruit. J. Sci. Food Agric. 61, 349-351. 